\title{
Tinjauan Etika Bisnis Islam terhadap Praktik Eksploitasi (Pemanfaatan Berlebih) pada Jual Beli Batu Kapur
}

\author{
Hanum Auliya Rahmah *, Nanik Eprianti \\ Prodi Hukum Ekonomi Syariah, Fakultas Syariah, Universitas Islam \\ Bandung, Indonesia. \\ *hanumauliya28@gmail.com, nanikeprianti@gmail.com
}

Abstract. Limestone resources have enormous potential in the mining business world, which is utilized by CV. Bintang Mas Kabupaten Bandung Barat. The purpose of this research is to understand mechanics of the practice of exploitation (over-use) that are done on industrial buying and limestone and to know the ethical review of the islamic business on the practice of exploitation on industrial limestone on $\mathrm{CV}$. Bintang Mas Kabupaten Bandung Barat. The methods used are descretive qualitative and research data types using field data. This thesis study reveals that the practice mechanism of exploitation was done by CV. Bintang Mas Kabupaten Bandung Barat does not use restrictions on its limestone taking away any restrictions on limestone taking away it causes environmental damage, so it can be concluded that the practice of exploitation is not consistent with the ethical principles of the islamic business as well as the production ethics in Islam.

Keywords: Ethics, Business, Eksploitation.

Abstrak. Sumber daya alam batu kapur mempunyai potensi yang sangat besar dalam dunia bisnis pertambangan, hal tersebut dimanfaatkan oleh CV. Bintang Mas Kabupaten Bandung Barat. Tujuan penelitian ini adalah mengetahui mekanisme praktik eksploitasi (pemanfaatan berlebih) yang dilakukan pada jual beli batu kapur untuk industri dan mengetahui tinjauan etika bisnis Islam terhadap praktik eksploitasi pada jual beli batu kapur untuk industri di CV. Bintang Mas Kabupaten Bandung Barat. Metode yang digunakan adalah kualitatif deskriftif dan jenis data penelitian menggunakan data lapangan. Hasil penelitian skripsi ini menyebutkan bahwa mekanisme praktik eksploitasi (pemanfaatan berlebih) yang dilakukan oleh CV. Bintang Mas Kabupaten Bandung Barat ini tidak menggunakan pembatasan dalam pengambilan batu kapurnya Tidak adanya pembatasan dalam pengambilan batu kapur menyebabkan kerusakan lingkungan, maka dapat disimpulkan bahwa praktik eksploitasi tersebut tidak sesuai dengan prinsip etika bisnis Islam juga etika produksi dalam Islam

Kata Kunci: Etika, Bisnis, Eksploitasi 


\section{A. Pendahuluan}

Sebagai pelaku usaha, dalam menjalankan usahanya harus memperhatikan etika yang ada. Nilainilai dasar Al-Quran dan Hadist, dan sumber lainnya merupakan sumber yang tidak boeh dilepaskan ketika melakukan kegiatan ekonomi. Dengan aturan tersebut akan memudahkan seseorang dalam menjalankan bisnis yang menguntungkan dan selalu berada dijalan yang benar yaitu jalan Allah yang ketentuannya telah ditetapkan dan harus kita terapkan. (Amalia, 2014)

Mengikuti perintah Allah dan menjauhi larangannya merupakan perilaku moral yang harus diterapkan dalam kegiatan ekonomi. Nilai-nilai Islam yang mengutamakan kehalalan dan keharaman adalah suatu nilai yang dapat mencerminkan seorang pelaku usaha dalam berbisnis, karena dalam berbisnis harus menerapkan etika yang sesuai dengan prinsip Islam. Sebagaimana firman Allah dalam Qs. Al- Nisa [4] ayat 29:



"Hai orang-orang yang beriman, janganlah kamu saling memakan harta sesamamu dengan jalan batil, kecuali dengan jalan perniagaan yang berlaku dengan suka sama suka diantara kamu. Dan janganlah kamu membunuh dirimu, sesungguhnya Allah maha penyayang kepadamu."

Prinsip kesatuan (Unity), Keseimbangan (Equilibirium), Kehendak bebas (Free Will), Tanggung Jawab (Responsibility), Kebenaran: Kebajikan dan kejujuran merupakan prinsip Islam harus diutamakan dalam sistem ekonomi syariah karena merupakan aspek yang sangat penting dalam aktivitas bisnis seorang pelaku usaha. (Darmawati, 2013)

Jual beli adalah salah satu kegiatan dalam berbisnis, maka dari itu dalam salah satu prinsip etika bisnis menurut Islam tidak diperkenankan untuk melakukan praktik eksploitasi. Tindakan yang bertujuan untuk mendapatkan keuntungan tetapi dengan menggunakan tindakan yang berlebihan dan sewenang-wenang juga dapat merusak sumber daya alam disebut dengan ekploitasi.

Dalam konteks etika bisnis Islam, para pelaku usaha harus memperhatikan beberapa hal penting ketika melakukan produksi, yaitu harus memperhatikan prinsip-prinsip etika dalam berproduksi, salah satunya adalah melindungi alam dan seisinya. Menjaga alam dan seisinya merupakan tindakan yang harus dilakukan sebagai bentuk mensyukuri nikmat Allah, hal tersebut merupakan kewajiban kita sebagai manusia yang diutus Allah sebagai khalifah di muka bumi ini. Salah satu cara mensyukuri nikmat tersebut adalah dengan menjaganya dari pencemaran, kerusakan atau kehancuran. Allah SWT berfirman dalam surat Al-A'raf [7] ayat 85:



"Dan janganlah kamu membuat kerusakan di muka bumi sesudah Tuhan memperbaikinya. Yang demikian itu lebih baik bagimu jika betul-betul kamu orang-orang yang beriman.

Ada beberapa hal yang harus diperhatikan dalam etika bisnis, salah satunya adalah aspek hukum yang harus diterapkan seperti pengakuan kepemilikan, pengelolaan dan pembagian harta. Maka dalam etika bisnis Islam dilarang untuk melakukan monopoli, menolak tindakan eksploitasi, diskriminasi, dan harus adanya keseimbangan antara hak dan kewajiban serta menghindari bisnis yang tidak sehat. (Mardani, 2014)

Peneliti mengambil objek penelitian di perusahaan CV. Bintang Mas Kabupaten Bandung Barat. Sumber daya alam batu kapur merupakan sumber daya alam paling banyak yang berada di wilayah Kabupaten Bandung Barat, hal tersebut dimanfaatkan oleh investor atau pengusaha untuk membuka usaha tersebut seperti halnya yang dilakukan oleh CV. Bintang Mas Kabupaten Bandung Barat. Tapi dalam praktiknya penambangan dan pengelolaan batu kapur yang dilakukan oleh CV. Bintang Mas Kabupaten Bandung Barat. mengakibatkan eksploitasi yang terlalu berlebih sehingga menyebabkan terkikisnya atau berkurangnya sumber daya alam, menghasilkan polusi yang sangat pekat akibat dari pembakaran batu kapur menggunakan bahan bakar karet dan sampah, dan juga dampak polusi tersebut sudah sampai ke pemukiman sehingga banyak merugikan penduduk setempat seperti debu yang sampai teras rumah, dan baju yang 
dijemur menjadi kotor kembali akibat debu.

Berdasarkan latar belakang yang telah diuraikan, maka rumusan masalah dalam penelitian ini sebagai berikut:

1. Bagaimana mekanisme praktik eksploitasi (pemanfaatan berlebihan) pada jual beli batu kapur yang dilakukan CV. Bintang Mas Kabupaten Bandung Barat?

2. Bagaimana tinjauan Etika Bisnis Islam terhadap praktik eksploitasi (pemanfaatan berlebih) pada jual beli batu kapur di CV. Bintang Mas Kabupaten Bandung Barat?

\section{B. Metodologi}

Penelitian ini menggunakan metode kualitatif deskriftif. Dimana untuk mencapai tujuan dari penelitian, sangat memerlukan tinjauan lebih dalam terkait penelitian tersebut. Untuk mengetahui adanya praktik eksploitasi yang dilakukan oleh CV. Bintang Mas Kabupaten Bandung Barat ini memerlukan metode kualitatif deskriftif karena peneliti dapat mengobservasi data secara mendalam dan turun langsung ke lapangan dengan mengetahui fakta-fakta yang ada, yang nantinya akan disesuaikan dengan memperhatikan secara langsung mekanisme yang dilakukan CV. Bintang Mas Kabupaten Bandung barat dalam pengambilan sumber daya alam berupa batu kapur. Hal tersebut akan mempermudah dalam teknik analisis data untuk dikontruksikan kedalam hasil penelitian.

Pendekatan penelitiannya menggunakan pendekatan empiris dengan jenis data penelitian menggunakan data lapangan (field research), data yang digunakan adalah data primer sebagai data langsung dan data sekunder sebagai data pendukung. Teknik pengumpulan datanya menggunakan observasi, wawancara, dan dokumentasi dan teknik analisis data menggunakan tahapan reduksi data, penyajian data, dan penarikan kesimpulan.

\section{Hasil dan Pembahasan}

Mekanisme Praktik Eksploitasi (pemanfaatan berlebih) pada jual beli batu kapur yang dilakukan CV. Bintang Mas Kabupaten Bandung Barat

Penambangan batu alam seperti batu kapur dan marmer adalah kegiatan yang berpotensi besar untuk menaikan perekonomian masyarakat di Kabupaten Bandung Barat, karena Kabupaten Bandung Barat merupakan wilayah dengan sumber daya alam batu paling banyak khususnya di daerah Padalarang, seperti halnya yang dilakukan oleh CV. Bintang Mas Kabupaten Bandung Barat.

Penambangan dilakukan oleh profesional karena kegiatan tersebut termasuk ke dalam kegiatan yang berbahaya. Penambang dibantu dengan alat berat seperti beko, baket, totrok, dan pensil beko untuk mengambil langsung batu yang ada di gunung, karena ukuran batu yang pertama kali diambil tersebut sangat besar maka akan dibantu kembali oleh penumbuk batu menggunakan alat sederhana seperti linggis dan palu untuk dipecahkan dan dibuat menjadi bagian yang lebih kecil. Batu yang telah ditumbuk menjadi ukuran yang lebih kecil akan di angkut menggunakan truk untuk dibawa ke bagian produksi, dan akan diolah kembali melalu proses pembakaran dan penggilingan yang akan menghasilkan sebuah produk diantaranya adalah Kalsium, $\mathrm{CaO}$, dan $\mathrm{Ca}(\mathrm{OH})_{2 .}$. CV. Bintang Mas Kabupaten Bandung Barat tidak menerapkan pembatasan dalam penambangan batu kapur tersebut, dikarenakan banyaknya permintaan dari konsumen maka kegiatan penambangan dan pengelolaan batu kapur terus dilakukan setiap harinya.

Dalam kaitannya dengan hal kerusakan lingkungan, pencemaran udara, dan pemanfaatan sumber daya alam yang terlalu berlebih (eksploitasi), aktivitas penambangan dan pengelolaan batu kapur yang dilakukan oleh CV. Bintang Mas Kabupaten Bandung Barat bisa digolongkan kedalam aktivitas merusak lingkungan meskipun dalam kenyataannya perusahaan tersebut sudah mengantongi surat izin usaha pertambangan dan surat izin usaha mendirikan perusahaan tersebut.

Tinjauan Etika Bisnis Islam terhadap praktik eksploitasi (pemanfaatan berlebih) pada jual beli batu kapur di CV. Bintang Mas Bandung Barat

Dapat diketahui bahwa mekanisme penambangan dan pengelolaan batu kapur oleh CV. Bintang Mas Kabupaten Bandung Barat itu digolongkan kepada pemanfaatan batu kapur yang terlalu 
berlebih sehingga menyebabkan banyaknya kerugian yang dialami, kerugian tersebut berdampak kerusakan lingkungan dan kenyamanan masyarakat sekitar. Hal ini memberikan dampak secara langsung, sehingga pelaku bisnis hanya mementingkan keuntungan saja tanpa memperhatikan dampak yang akan terjadi dilingkungan sekitar penambangan pasir tersebut.

CV. Bintang Mas Kabupaten Bandung Barat dalam pelaksanaanya belum menerapkan prinsip tauhid (Julianty, 2016), karena mekanisme penambangan dan pengelolaan batu kapur tersebut tidak memperhatikan lingkungan dan memanfaatkan sumber daya alam yang terlalu berlebih (eksploitasi) yang menyebabkan terkikisnya sumber daya alam. Selain itu belum menerapkan prinsip keseimbangan dimana dalam mekanisme penambangan dan pengelolaan batu kapur tersebut tidak ada pembatasan,

Mekanisme penambangan dan pengelolaan batu kapur CV. Bintang Mas Kabupaten Bandung Barat masih bertentangan dengan prinsip keseimbangan (Arijano, 2014), karena pada praktiknya banyak menimbulkan keresahan bagi warga, dimulai dari adanya polusi udara, dan kerusakan lingkungan di wilayah pertambangan yang dikhawatirkan menyebabkan bencana seperti longsor, sedangakan dalam prinsip kehendak bebas seorang pelaku bisnis itu bebas melakukan hal apapun dalam bisnisnya dengan syarat tanpa merugikan orang lain.

Mekanisme penambangan dan pengelolaan batu kapur CV. Bintang Mas Kabupaten Bandung Barat masih bertentangan dengan prinsip kehendak bebas, karena pada praktiknya banyak menimbulkan keresahan bagi warga, dimulai dari adanya polusi udara, dan kerusakan lingkungan di wilayah pertambangan yang dikhawatirkan menyebabkan bencana seperti longsor, sedangakan dalam prinsip kehendak bebas seorang pelaku bisnis itu bebas melakukan hal apapun dalam bisnisnya dengan syarat tanpa merugikan orang lain. Penambangan dan pengelolaan sumber daya alam yang dilakukan oleh CV. Bintang Mas Kabupaten Bandung Barat ini belu menerapkan prinsip tanggung jawab (Muslich, 2004), dimana dalam pelaksanaanya masih merugikan masyarakat sekitar.

Sesuai dengan firman Allah dalam surat Al-A'raf [7] ayat 85:

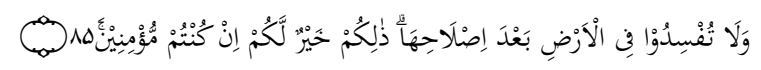

"Dan janganlah kamu membuat kerusakan di muka bumi sesudah Tuhan memperbaikinya. Yang demikian itu lebih baik bagimu jika betul-betul kamu orang-orang yang beriman ayat ini dijelaskan bahwa sebagai manusia alam semesta beserta isinya harus dijaga dengan baik tanpa membuat kerusakan di muka bumi ini, dan di haruskan untuk melindungi dan melestarikan sumber daya alam,memanfaatkan dengan sebaik-baiknya dan lebih bijaksana. Seperti halnya yang dilakukan oleh CV. Bintang Mas Kabupaten Bandung Barat ini dalam penambangan dan pengelolaan batu kapur tidak memperhatikan batasan-batasan yang ada tetapi terus mengikuti banyaknya permintaan yang ada. Padahal, dengan pembatasan ini, umat manusia harus melakukan pembatasan untuk menghindari adanya kehancuran yang disebabkan oleh kegiatan pelestarian lingkungan yang tidak disengaja oleh industri pertambangan.

Fatwa Majelis Ulama Indonesia Nomor: 22 Tahun 2011 Tentang Pertambangan Ramah Lingkungan. (MUI, 2011) Menjelaskan bahwa selama dilakukan untuk kebaikan umum maka kegiatan pertambangan boleh dilakukan, tidak mendatangkan kehancuran dan tetap menjaga lingkungan. Tapi pada pelaksanaanya CV. Bintang Mas Bandung Barat ini bertentangan dengan fatwa MUI ini, dimana masih mementingkan kepentingan sendiri untuk memenuhi permintaan konsumen dengan melakukan pertambangan setiap harinya tanpa melakukan pembatasan, hal tersebut juga mendatangkan kerusakan pada lingkungan dimana banyaknya lubang-lubang bekas penambangan yang membahayakan dan dikhawatirkan terjadinya bencana longsor. Untuk pembuangan limbah asap yang sangat pekat itupun belum ada alat yang dapat menetralisir asap agar tidak terlalu mencemari udara.

UU No. 32 Tahun 2009 pasal 1 ayat (2) tentang perlindungan dan pengelolaan lingkungan hidup (Kemenkeu, 2009)bahwa sebagai pelaku bisnis khususnya di bidang pertambangan dianjurkan untuk menjaga lingkungan hidup dan mengelolanya dengan baik dengan tidak merusak lingkungan, harus dilakukannya pengendalian dalam pengambilan batu kapur, dan pemeliharaan juga pengawasan ketika sudah melakukan penambangan dan pengelolaan batu kapur, jangan sampai merusak sumber daya alam dan merugikan masyarakat 
setempat.

\section{Kesimpulan}

Berdasarkan pembahasan dalam penelitian ini, peneliti menyimpulkan beberapa hasil penelitian sebagai berikut:

1. Mekanisme praktik eksploitasi (pemanfaatan berlebih) pada jual beli batu kapur yang dilakukankan oleh CV. Bintang Mas Kabupaten Bandung Barat digolongkan kepada aktivitas yang merusak lingkungan, karena pada mekanismenya tidak ada pembatasan terhadap pengambilan batu kapur tersebut dimana batu kapur adalah sumber daya alam yang pada dasarnya tidak dapat di perbaharui.

2. Berdasarkan tinjauan etika bisnis Islam praktik eksploitasi (pemanfaatan berlebih) pada jual beli batu kapur yang dilakukan oleh CV. Bintang Mas Kabupaten Bandung Barat belum sesuai dengan prinsip-prinsip etika bisnis Islam yaitu prinsip kesatuan, prinsip keseimbangan, prinsip kehendak bebas, dan prinsip tanggung jawab. Selain itu praktik eksploitasi (pemanfaatan berlebih) ini belum sesuai dengan etika produksi dalam Islam.

\section{Acknowledge}

Dalam penyusunan karya tulis ilmiah ini tidak terlepas dukungan dari berbagai pihak. Peneliti secara khusus mengucapkan terima kasih yang sebesar-besarnya kepada semua pihak yang telah membantu. Peneliti banyak menerima bimbingan, petunjuk dan bantuan serta dorongan dari berbagai pihak baik yang bersifat moral maupun material.

\section{Daftar Pustaka}

[1] Amalia, F. (2014). Etika Bisnis Islam: Konsep Dan Implementasi Pada Pelaku Usaha Kecil. Al-Iqtishad: Journal of Islamic Economics, 118.

[2] Arijano, A. (2014). Etika Bisnis Bagi Pelaku Bisnis. Jakarta: PT. Raja Grafindo Persada.

[3] Darmawati, H. (2013). Etika Bisnis dalam Persfektif Islam: Eksplorasi Prinsip Etis Al-Quran dan Sunnah. Etika Bisnis Persfektif Islam, 7-8.

[4] Julianty, E. (2016). Etika Bisnis Dalam Persfektif Islam. Ummul Quran, 64.

[5] Kemenkeu. (2009, April 20). Kementrian Keuangan. Diambil kembali dari Kementrian Keuangan: https://jdih.kemenkeu.go.id/fullText/2009/4TAHUN2009UU.htm

[6] Mardani. (2014). Hukum Bisnis Syariah edisi pertama. Jakarta: Prenadamedia Group.

[7] MUI. (2011, April 14). Majelis Ulama Indonesia. Diambil kembali dari Lembaga Pemuliaan Lingkungan Hidup dan Sumber Daya Alam-MUI: https://mui-lplhsda.org/fatwa-majelisulama-indonesia-nomor-22-tahun-2011-tentang-pertambangan-ramah-lingkungan/

[8] Muslich. (2004). Etika Bisnis Islam (Landasan Filosofis, Normatif, Substansi Implementasi). Yogyakarta: Cv Adipura.

[9] Sulfana, M. A. (t.thn.). Tinjauan Etika Bisnis Islam Terhadap Penambangan Pasir Di Desa Pasir Sakti Lampung Timur. Skripsi, 13. 